\title{
Digitised products: how compliant is South African value-added tax?
}

\author{
RD de Swardt \\ Department of Taxation \\ University of Pretoria
}

R Oberholzer
Department of Taxation
University of Pretoria

\begin{abstract}
E-commerce has changed the way in which business is conducted. One instance of this is that it has made the digitisation of products possible. This shift has severe implications for traditional consumption taxes, which were developed under the premise of a physical presence in a tax jurisdiction. A large number of countries in the world that impose Value-Added Tax (VAT) on the supply of goods and services, including South Africa, are affected by this shift. The Organisation for Economic Cooperation and Development (OECD) has suggested a number of principles that should apply to consumption taxes in e-commerce. These principles are intended to provide fiscal climates in which e-commerce can flourish and ensure taxation systems that secure individual countries' tax bases. A comparison between the OECD principles and the rules pertaining to the imposition of VAT in South Africa on the supply of digitised products reveals several discrepancies and uncertainties. A baseline survey among VAT specialists in South Africa, conducted in order to substantiate these findings, confirmed these discrepancies and uncertainties in practice.
\end{abstract}

\section{Key words}

Consumption tax

E-commerce

Digitisation

Digitised products

South Africa

$O E C D$

Value-Added Tax

\section{Introduction}

The advent of e-commerce has created a rapidly expanding non-traditional market. Consumers have more choices, and cross-border transactions have increased. Over the last few years, e-commerce has gradually grown into what has arguably become the biggest challenge for modern tax systems to date (Du Plessis 2001:15). The number of online retail sites in South Africa has already grown substantially - from 719 at the end of 2003 to 826 at the end of 2005. The total amount spent on online retail goods in South Africa in 2005

Meditari Accountancy Research Vol. 14 No.1 2006 : 15-28 
was R514-million (up from R428-million in 2004) and a further $20 \%$ increase is anticipated in 2006 (World Wide Worx 2006). The digitisation of commerce specifically affects consumption taxes, such as Value-Added Tax (commonly referred to as VAT) and Sales Tax. This is mainly due to the fact that consumption taxes were developed under the premise of the physical presence of a product within a specific taxation jurisdiction ( $\mathrm{Du}$ Plessis 2001:15). However, with e-commerce, such a physical presence is no longer necessary.

Doernberg, Hinnekens and Hellerstein (2001:12) define digitisation as a process whereby information is converted into a sequence of numbers. The information converted in such a way can be images, speech, music, diagrams or the written word. As part of e-commerce, digitised information can then be sent throughout the world via the Internet, by means of a telephone or cable network or by satellite. The recipient can then convert the information back into its original format. Examples of digitised products are the online supply and updating of software by means of a digital download, the online supply of images, text and information, the availability of databases, the online supply of music, films and games, and distance teaching (Lejeune 2002:62).

During the 1990s, the Organisation for Economic Co-operation and Development (OECD) initiated a study project on the tax consequences of electronic commerce (Hammer 2004:106). The OECD was soon recognised as an international leader and catalyst in advancing the debate on international tax aspects of e-commerce (Teltscher 2002:1141). During 1998, the OECD agreed on a number of generally accepted tax principles, usually referred to as the Taxation Framework Conditions that should apply to the taxation of ecommerce.

Since then, the OECD has focused on the practical implementation of the principles that should apply to the imposition of consumption tax on e-commerce. This has resulted in the development of a 'Consumption Tax Guidance Series' through which, at present, a set of papers on the consumption tax issues of e-commerce is presented. The rationale for the Consumption Tax Guidance Series is to eliminate conflict in, distortions and disincentives to international trade (OECD 2003a:20). Although South Africa is not a member country of the OECD and is not bound by the OECD's consumption tax principles on e-commerce, it is prudent to consider these principles when evaluating current South African VAT legislation. E-commerce is by its very nature international, and international consensus on taxation principles applicable to e-commerce is essential (Fridensköld 2004:176). Governments have to provide a fiscal climate in which e-commerce can flourish and develop to its full potential, but must also operate a fair and predictable taxation system that secures their tax base and their ability to raise the revenue they require to meet the legitimate expectations of their citizens regarding public services (Fridensköld 2004:182).

For the past six years, South Africa has collected an average of $25 \%$ of its total tax revenue from VAT, which places South Africa among the five countries in the world that have the highest ratio of VAT to total revenue collected, according to the Budget Reviews of 2003 (South Africa 2003) and 2004 (South Africa 2004). According to Teltscher (2002:1138), there is a legitimate concern, especially among the governments of developing countries, about potential tax base erosion due to e-commerce, if domestic and international rules are not modified to take into account e-commerce developments. It is essential that the South African government ensures that tax base erosion does not occur due the development of e-commerce. This threat was highlighted in the South African Department of Communication's Green Paper on E-Commerce (South Africa 2000:28) as one of the 
biggest challenges that the South African government will have to address regarding ecommerce from a taxation point of view.

The Internet is still in its infancy in Africa (Carstens \& Lucouw 2004:27) and one could argue that e-commerce does not, at present, pose a significant threat to the South African consumption tax base. However, as Doernberg et al. (2001:2) observe, although ecommerce currently represents only a small percentage of total world commerce, it is growing at a significant rate and it is therefore not premature to examine its possible implications for taxation systems. It is imperative that the South African government considers the impact that e-commerce has, or may have, on consumption tax in South Africa.

\section{Research problem}

VAT was introduced in South Africa during 1991, replacing General Sales Tax. To date, no amendments have been made to the South African Value-Added Tax Act 89 of 1991 (the VAT Act) to ensure that it specifically provides for imposing VAT on the supply of digitised products (South Africa 1991a). The question to be considered is whether the South African VAT Act in its current form in fact provides for the imposition of VAT on the supply of digitised products and whether imposing VAT is consistent with the principles formulated by the OECD.

\section{Objectives of the study}

This study was designed to evaluate the imposition of VAT in South Africa on the supply of digitised products in terms of current South African VAT legislation, read against the consumption tax principles of e-commerce adopted by the OECD. The study also attempts to determine the perceptions held by a sample of VAT specialists in South Africa on the application of current VAT rules in South Africa to the supply of digitised products.

\section{Research methodology}

The principles advocated by the OECD on the imposition of consumption taxes on ecommerce were analysed. Current South African VAT legislation was also analysed in order to establish the rules pertaining to the imposition of VAT in South Africa on the supply of digitised products and to determine whether such rules are consistent with the OECD's principles.

In order to substantiate the findings of the analysis of current South African VAT legislation on the imposition of VAT on the supply of digitised products, a baseline survey was then conducted among VAT specialists from the six largest accounting firms in South Africa and from South African universities that are accredited by the South African Institute for Chartered Accountants (SAICA). The six accounting firms are PricewaterhouseCoopers Inc, Deloitte \& Touche, KPMG, Ernst \& Young South Africa, Grant Thornton Kessel Feinstein and BDO Spencer Steward. These institutions were contacted and requested to nominate a VAT specialist in each institution. The survey was administered electronically to twenty nominees and yielded a response rate of $60 \%$. The survey consisted of a questionnaire designed to test the perceptions of South African VAT specialists about the application of current VAT legislation in South Africa on the supply of digitised products. 
The questionnaire used a case study of a consumer who purchased computer software (for example, anti-virus software) from a supplier by means of a once-off download from the supplier's website as the point of departure for the study. The purchase price was settled by means of an electronic transfer of funds from the consumer's credit card account. The consumer was located in South Africa and the supplier in a country other than South Africa. The supplier had no business presence in South Africa, other than the exposure through its website. Other variables were included in the case study in order to evaluate current VAT rules in South Africa that apply in various circumstances.

\section{Comparison between OECD principles and the current South African VAT Act}

Several discrepancies, uncertainties and similarities were identified when the OECD principles on consumption tax in e-commerce were compared with the rules pertaining to the imposition of VAT in South Africa on the supply of digitised products. These problems areas are discussed below.

\subsection{Applying conventional commerce principles}

\section{The OECD principle}

A primary principle that the OECD agreed on was that the tax provisions that apply to conventional commerce should also apply to e-commerce. This principle eliminated the possibility that e-commerce would become tax-free, or that governments could impose a discriminatory tax on e-commerce (OECD 1998a:3).

\section{The South African VAT system}

The current South African VAT Act makes no specific reference to the imposition of VAT on the supply of digitised products. The implication of this is that the basic principles that underlie the imposition of VAT on conventional transactions should also apply to ecommerce transactions, and hence to the supply of digitised products.

\subsection{Classification of digitised products}

\section{The OECD principle}

In general, VAT systems distinguish between the supply of goods and the supply of services. The classification of digitised products for VAT purposes as either goods or as services has a fundamental effect on the rules that apply to the imposition of VAT on the supply of such services. The OECD has agreed that, for consumption tax purposes, digitised products should not be classified as goods (OECD 1998a:5). This principle implies that, under most tax systems, the supply of digitised products will be regarded as a supply of services.

\section{The South African VAT system}

From an analysis of the definition of goods in section 1 of the South African VAT Act, it is apparent that digitised products cannot be classified as goods. To be classified as goods in terms of the definition of goods, a product has to be a physical object or a real right in a physical object. Although a digitised product in its conventional form, such as a newspaper that is purchased over the counter, is regarded as a supply of corporeal property, digitisation 
allows suppliers to deliver the information to customers in a digitised form, which cannot be classified as a supply of corporeal property. The supply of digitised products can only be classified as incorporeal property, according to the Canadian Customs and Revenue Authority (CCRA 2002:4). The definition of services in section 1 of the South African VAT Act, however, is broadly formulated and is considered to be a 'catch-all concept' that includes everything that does not constitute goods (De Koker \& Kruger 2004:§3.3). It can therefore be concluded that, for South African VAT purposes, digitised products should be classified as services.

Although the results from the survey that was conducted amongst VAT specialists in South Africa indicate that the majority of the respondents concur with the classification of the supply of digitised products as a supply of services, $17 \%$ of the respondents indicated that they thought that digitised products should be classified as goods and $8 \%$ of the respondents indicated that digitised products could be goods or services, depending on the product. These results indicate that there is some uncertainty regarding the classification of digitised products for South African VAT purposes.

\subsection{Taxation in the jurisdiction where consumption takes place}

\section{The OECD principle}

An essential part of the challenge of avoiding double consumption tax or unintentional nontaxation on cross-border e-commerce supplies of digitised products is reaching international consensus on the jurisdiction in which consumption tax should be imposed. In implementing the general taxation principles that should apply to e-commerce, the OECD concluded that the rules for levying consumption tax on the cross-border supply of digitised products should result in taxation in the jurisdiction where consumption takes place (OECD 1998a:5).

Applying the principle of taxation on the supply of digitised products at the place of consumption can, however, only be effective if international consensus is reached on the circumstances under which supplies are held to be consumed within a specific jurisdiction (OECD 1998a:5). In an attempt to promote international consensus in identifying the place of consumption for a specific supply, the OECD has agreed on a definition for the 'place of consumption' (OECD 2001:24).

In arriving at a definition for the place of consumption, the OECD first considered a pure definition of consumption, in terms of which tax should accrue to the country in which the actual consumption takes place. However, due to the global nature of e-commerce, combined with the mobility created by the latest communication methods, the OECD concluded that a pure place of consumption test would at present result in a considerable, and in some cases impossible, compliance burden for vendors and administrative difficulties for revenue authorities (OECD 2001:12).

In order for compliance burdens to be kept to a minimum and to allow for easy and efficient collection by tax administrations, the OECD defines the place of consumption for cross-border supplies of services and intangible property that are capable of direct delivery from a remote location for business-to-business (B2B) transactions as the place where the recipient has located its business presence; and for business-to-consumer (B2C) transactions as the jurisdiction where the customer has his or her usual place of residence (OECD 2001:24). 
The recipient's business presence is, in principle, the establishment (for example, the recipient's headquarters, registered office, or branch) to which the supply is made. Where the recipient has a business presence in more than one jurisdiction, the place of consumption of a specific supply refers to the location of the business presence to which that supply is made (OECD 2001:24). The OECD is of the opinion that normal commercial practices, as evidenced in the terms of the contract between a supplier and a recipient (such as invoicing, the terms of payment and the use of intellectual property), normally provides sufficient information to assist the supplier and revenue authorities in determining where the recipient's business presence is located (OECD 2003c:4).

In terms of a B2C transaction, the recipient's presence is not an effective proxy for determining the place of consumption. The OECD defines the place of consumption with regard to $\mathrm{B} 2 \mathrm{C}$ transactions as the jurisdiction in which the recipient has his or her usual place of residence. The OECD is of the opinion that, although this approach is not a theoretically pure definition of the place of consumption and may not always result in taxation in the actual place of consumption, it is at present the most practicable option in ecommerce (OECD 2001:25).

The OECD principle that the place of consumption should be the place of taxation for cross-border e-commerce supplies and the OECD guidelines for defining the place of consumption for $\mathrm{B} 2 \mathrm{~B}$ and $\mathrm{B} 2 \mathrm{C}$ e-commerce transactions significantly reduce the possibility of double taxation or unintentional non-taxation (OECD 2003b:3).

\section{The South African VAT system}

The South African VAT system is a destination-based system (De Koker \& Kruger 2004:\$1.4), which implies that goods and services are taxed where the consumer is situated. Services are therefore taxed in South Africa if the consumer is located in South Africa. Services supplied by suppliers located within South Africa are relieved from tax if the consumer is located outside South Africa. This approach generally relies on proxies to determine whether consumption is considered to take place outside the jurisdiction (OECD 2004:6).

An unusual feature of the South African VAT system is that it does not, unlike other VAT jurisdictions, use specific 'place of supply rules' to determine whether a supply is subject to VAT in South Africa (De Koker \& Kruger 2004:§3.1). The definition of an enterprise in section 1 of the South African VAT Act and the VAT import and export rules operate together to determine whether or not consumption of a service is considered to have taken place in South Africa and is consequently subject to South African VAT.

Section 7(1)(a) of the South African VAT Act requires a vendor to impose VAT on a supply made if that vendor is carrying on an enterprise and the supply is made in the course or furtherance of that enterprise. The definition of an enterprise in section 1 of the VAT Act requires an activity to be conducted continuously or regularly in, or partly in, South Africa.

From the survey conducted among VAT specialists in South Africa, it is evident that there is great uncertainty regarding whether a foreign supplier that supplies digitised products to persons located in South Africa is carrying on an enterprise in South Africa. Half of the respondents indicated that they thought such a foreign supplier is indeed carrying on an enterprise in South Africa, and the other half indicated that the supplier is not. This lack of consensus indicates uncertainty as to whether the VAT Act imposes an obligation on such a foreign supplier to charge South African VAT on the supply and to remit the amount to the South African Revenue Services. 
Whether a foreign supplier provides a once-off electronic supply of digitised products to a recipient in South Africa, or in addition also provides regular (for example, weekly or monthly) electronic updates thereof makes no difference in determining whether the supplier is carrying on an enterprise in South Africa, according to the respondents to the survey. Half of the respondents still considered the supplier not to be carrying on an enterprise in South Africa.

The respondents were required to comment on the effect of the location of the server on which a foreign supplier's website is hosted on whether or not the supplier is carrying on an enterprise in South Africa. The opinion of the majority of the respondents $(75 \%)$ is that a foreign supplier is carrying on an enterprise in South Africa if its website is hosted on a server located in South Africa. These respondents did not consider ownership of the server to be a relevant factor. The majority of the respondents (91\%) agreed that the foreign supplier would be carrying on an enterprise in South Africa if it had a business presence such as a branch with an office operating a call centre in South Africa.

It is evident that whether the activities of a foreign supplier who supplies digitised products to persons in South Africa constitutes an enterprise or activity that is carried on in or partly in South Africa is not clear. Beneke (2003:22) argues that the uncertainty is exacerbated by the fact that there are no 'place of supply rules' in the current South African VAT Act.

The lack of clarity regarding the question of when a foreign supplier is regarded as carrying on an enterprise in South Africa is a major deficiency in the current South African VAT system, specifically with regard to the imposition of VAT on the supply of digitised products. A foreign supplier has to make a real-time decision whether VAT should be imposed on a supply made to a person in South Africa. In the absence of clarity on whether a foreign supplier of digitised products is carrying on an enterprise in South Africa, the supplier will not be able to make the correct tax decision.

In the circumstance where a supplier is regarded as carrying on an enterprise in South Africa and is subsequently obliged to impose South African VAT on the supply of a digitised product, such supply is charged with VAT at a rate of zero per cent if the digitised product is exported. Section 11(2)(l) of the South African VAT Act allows for the zerorating of a supply of services that is made to a recipient that is not a resident of South Africa and not in South Africa at the time when the services are rendered.

An investigation into whether a customer is a resident of South Africa is complex and difficult, if not impossible, to apply in the context of e-commerce. The supplier has to determine whether the recipient is carrying on an enterprise or other activity in South Africa and has a fixed or permanent place of business in South Africa in connection with such an enterprise or activity. To the extent that this is the case, the recipient is considered to be a resident of South Africa for South African VAT purposes. If this is not the case, the supplier has to determine whether the recipient is a natural person or not. In the case where the recipient is a natural person, the person is considered to be a resident of South Africa for VAT purposes if the person ordinarily resides in South Africa, or if the person has been physically present in South Africa for a specific number of days during a five-year period. In the case where the recipient is a person other than a natural person, the person is considered to be a resident of South Africa for VAT purposes if the person's place of effective management is in South Africa, according to the South African VAT Act:

Meditari Accountancy Research Vol. 14 No.1 2006 : 15-28 
definition of resident of the Republic, section 1, South African Income Tax Act: definition of resident, section 1 (South Africa 1962).

The onus is on the vendor to prove that the requirements of section 11(2)(l) of the South African VAT Act are complied with, as shown in the case of the South African Rugby Football Union v Commissioner for South African Revenue Service (61 SATC 406). The VAT Act is silent on the process that a vendor must follow to verify that the recipient is not a resident of South Africa and is indeed outside South Africa at the time that the services are rendered.

The complexity of the definition of a resident of South Africa, the fact that the onus of proof is on the vendor and the lack of guidance in the VAT Act as to how to determine the residence status of a recipient creates a daunting task for a vendor who must decide on the VAT consequences of exporting digitised products from South Africa.

In the case where a foreign supplier of digitised products is not regarded to be carrying on an enterprise in South Africa, the supplier is not obliged to impose South African VAT on the supply of digitised products to recipients in South Africa. Section $7(1)(c)$ of the South African VAT Act then imposes an obligation on the recipient to self-assess the VAT due on the import of the digitised product and to pay the amount directly to SARS. In terms of the definition of 'imported services' in section 1 of the South African VAT Act, this obligation is only imposed on recipients that are non-vendors, and recipients that are vendors and not making wholly taxable supplies. The digitised product has to be consumed in South Africa and the recipient is furthermore only obliged to account for VAT on the import if the recipient is a resident of South Africa for VAT purposes and the supplier is not, or the supplier is carrying on a business outside South Africa - see the South African VAT Act: definition of imported services, section 1 (South Africa 1991). Apart from the complex requirements that have to be complied with for purposes of section $7(1)(c)$ of the South African VAT Act, the OECD does not consider a self-assessment VAT collection mechanism to be effective in these circumstances (OECD 2001:27). This collection mechanism inevitably poses a threat to the South African VAT tax base (Nunes 1999:84).

The OECD principle is that the rules for levying consumption tax on the cross-border supply of digitised products should result in taxation in the jurisdiction where consumption takes place (OECD 1998a:5). Although the South African VAT system is a destinationbased system, which implies that goods and services are taxed where the consumer is situated and where the goods and services are consumed, the rules that should give effect to this are unclear and difficult to apply in the context of international e-commerce. Uncertainty regarding the meaning of an enterprise creates uncertainty regarding a foreign supplier's obligation to impose South African VAT on a supply of digitised products to a recipient in South Africa. The rules that govern the application of a zero rate of tax on the export of digitised products from South Africa are not only complex, but also inconsistent with the OECD's definition of the place of consumption. Where an obligation is not placed on a foreign supplier to impose South African VAT on the supply of digitised products to persons located in South Africa, the recipient has to self-assess the VAT due. Self-assessing VAT in these circumstances is, however, considered to be ineffective. 


\subsection{Consumption tax collection mechanisms}

\section{The OECD principle}

As supplier registration and reverse charge or self-assessment collection mechanisms are in use in most consumption tax systems in the world, the OECD has concluded that these are at present the most appropriate mechanisms to apply to cross-border supplies of services and intangible property, thereby including digitised products (OECD 2001:26).

For B2B transactions, the OECD recommends that countries should apply a reverse charge or self-assessment collection mechanism (OECD 2001:26). This method of collecting VAT is, however, considered to be ineffective for $\mathrm{B} 2 \mathrm{C}$ transactions (OECD 2001:27). The OECD acknowledges that no single collection option for B2C transactions is without significant difficulties, but recommends, as a short-term solution, that governments should apply a system of simplified registration for non-resident suppliers where this is consistent with the overall design of the country's domestic consumption tax system (OECD 2001:27). As a medium-term to long-term approach, the OECD recommends that governments investigate technology-based options, such as computer software, to assist in the collection of VAT on B2C transactions (OECD 2001:18). The complexity of current consumption tax systems is, however, considered to be a vast constraint to the development of such computer software. International consensus regarding the classification of goods, remittance procedures, returns and the harmonisation of tax rates is required in order for technology to develop a feasible collection mechanism (OECD 2003e:5).

\section{The South African VAT system}

The current South African VAT Act makes provision for the collection of VAT on the supply of services, either by means of vendor registration or by means of self-assessment (South African VAT Act, sections 7(1)(a) and (c)). A vendor-registration method is used if a supplier is considered to be carrying on an enterprise in South Africa. If a foreign supplier that supplies digitised products to persons located in South Africa is not considered to be carrying on an enterprise in South Africa and is consequently not obliged to impose VAT on a transaction, the consumer is obliged to self-assess the amount of VAT due. This is only the case if the consumer is a resident of South Africa for VAT purposes and consumes the imported digitised products in South Africa. It has been shown earlier in this article that uncertainty currently exists regarding whether a foreign supplier that supplies digitised products to persons located in South Africa is carrying on an enterprise in South Africa. As such, a foreign supplier's obligation to impose South African VAT on a supply of digitised products to a person located in South Africa is not clear.

If it was the intention of the South African legislature to regard a foreign supplier that supplies digitised products to persons located in South Africa as carrying on an enterprise in South Africa, such a supplier should register as a vendor in accordance with section 23 of the South African VAT Act. The supplier has to register as a vendor only if its taxable supplies exceed the R300 000 registration threshold. This section makes no distinction between the registration procedure for foreign suppliers and local suppliers; and it consequently does not provide for a simplified registration of foreign suppliers, as recommended by the OECD.

If it was not the intention of the South African legislature to regard a foreign supplier that supplies digitised products to persons located in South Africa as carrying on an enterprise in South Africa, the supplier is not obliged to impose South African VAT on the 
transaction. A self-assessment collection mechanism then applies to the import of digitised products by non-vendors (or vendors making certain non-taxable supplies) that consume the products in South Africa, in terms of the South African VAT Act, section 7(1)(c), definition of 'imported services', section 1 (South Africa 1991). The OECD considers such a self-assessment collection mechanism to be the least effective collection mechanism (OECD 2001:27).

\subsection{Verification of customer's status and jurisdiction}

\section{The OECD principle}

Both the OECD principle that consumption taxation should take place in the jurisdiction where consumption takes place and the proposed VAT collection mechanisms depend largely on the customer's VAT status (that is, whether the customer is a registered vendor, and whether the transaction is $\mathrm{B} 2 \mathrm{~B}$ or $\mathrm{B} 2 \mathrm{C}$ ) and the tax jurisdiction in which the customer is located. Governments should, according to the OECD, provide business with clear, realistic and consistent guidelines on the nature and type of verification of a consumer's status that is required (OECD 2003d:2).

The OECD proposes that a supplier should be required to verify the VAT status of a customer with whom the supplier does not have an established relationship. Such verification should be by means of a comparison of the VAT registration number of the customer with a country's VAT registration database. A country's VAT registration database should be publicly available, preferably in an on-line format (OECD 2003d:3). Possible verification by means of digital certificates is also considered to be effective and reliable. The OECD recognises that digital certificates could supply information regarding the customer's VAT registration status and jurisdiction (OECD 2003d:6).

The OECD argues that payment system information would, in the short term, not be able to assist in verifying the VAT status of a consumer. Due to privacy protection, only minimal information is at present passed on to vendors, and the status of the cardholder cannot be derived from the current credit card system (OECD 2003d:5).

The OECD proposes that in verifying the taxation jurisdiction of a customer, information provided by means of geolocation software, digital certificates and, to some extent, payment system information should be used in investigating whether it corresponds with the customer's declaration (OECD 2003d:7).

The OECD recognises that current credit card information is able to assist to some extent in determining the taxation jurisdiction of the customer. Where confirmation of the billing address is required as part of the commercial processing of an on-line transaction, it could generally be expected that this should correspond with the customer's declaration of the customer's taxation jurisdiction (OECD 2003d:7).

Geolocation software makes it possible to identify the location of the customer at the time of the transaction accurately. This software makes use of an Internet user's Internet Protocol (IP) address in determining the location of the Internet user. This is done by comparing the destination IP number of an Internet user to a database of known IP numbers. According to the OECD, the software is between $85 \%$ and $96 \%$ accurate in determining the location of a customer at the time of an on-line transaction. The customer's location should generally correspond to the declared taxation jurisdiction (OECD 2003d:7). 
The OECD recognises that digital certificates offer the best possibilities in the long term in verifying the taxation jurisdiction of a private customer. At present, however, digital certificates are not widely used by private customers (OECD 2003d:7).

The OECD submits that government authorities should provide clear guidelines on what a supplier should do if the customer's declaration does not correspond with the customer's billing address, the customer's location at the time of the transaction as determined by means of geolocation software or the information provided by means of a digital certificate. These guidelines should attempt to strike a balance between business concerns regarding lost sales and the need for tax certainty and the protection of the government's consumption tax base (OECD 2003d:7).

\section{The South African VAT system}

At present the South African Revenue Services provides for a VAT vendor search on its website, where persons can verify the authenticity of a VAT vendor number. However, the South African VAT Act does not provide suppliers with guidelines on how to verify the status and jurisdiction of a consumer. This creates difficulties, particularly for South African registered vendors that export digitised products to persons located outside South Africa. Section 11(2) $(l)$ of the South African VAT Act allows for the zero-rating of a supply of services made to a recipient that is not a resident of South Africa and not in South Africa at the time when the services are rendered. As demonstrated earlier in this article, the onus is on the vendor to prove that the requirements of the section are complied with.

In the survey that was conducted among VAT specialists in South Africa, $75 \%$ of the respondents identified problems with applying section $11(2)(l)$ of the South African VAT Act. Some of the problems that were identified are the following:

it would be difficult for the supplier to prove that the consumer is not in South Africa at the time when the digitised products are supplied;

the place of residence of the recipient of the services (outside South Africa) is not conclusive proof that the services will be consumed outside South Africa;

the onus of proof is on the supplier; and

it will be difficult for suppliers to confirm that a consumer is not a resident of South Africa.

It was evident from the survey that verifying a customer's status and location in ecommerce in the absence of legislative guidance is considered problematic. South African registered vendors will consequently experience difficulty in zero-rating the export of digitised products in accordance with section 11(2)(l). As a result, it is possible that such vendors would choose to impose VAT on the export and consequently jeopardise the OECD's principle of taxation at the place of consumption.

\section{Conclusion and recommendations}

The South African government has to provide a fiscal climate in which e-commerce in South Africa can reach its full potential and, at the same time, ensure that the correct amount of revenue is collected to fund government expenditure (Fridensköld 2004:182). This can best be achieved if international consumption tax principles of e-commerce are followed. 
The OECD has recommended principles that should apply to consumption taxes in ecommerce. These principles are intended to provide fiscal climates in which e-commerce can flourish and, at the same time, ensure that taxation systems will secure individual countries' tax bases (OECD 1998a:3). A comparison between the OECD principles and the rules pertaining to the imposition of VAT in South Africa on the supply of digitised products has identified several discrepancies and uncertainties. These findings were substantiated by the results of the survey conducted among South African VAT specialists.

The OECD principle of classifying digitised products as services for VAT purposes is considered to be applicable in South Africa. It is, however, recommended that in order to ensure that the principle is applied consistently, the principle should be confirmed in the South African VAT Act.

It is imperative that the VAT Act provides clarity as to whether a vendor-registration or self-assessment collection mechanism is to be applied in collecting VAT on the supply of digitised products by a foreign supplier. At present, the definition of an enterprise does not provide clarity regarding whether a foreign supplier who supplies digitised products to persons located in South Africa is considered to be carrying on an enterprise. Consequently, it is not clear whether an obligation to charge VAT and remit the amount to the South African Revenue Services is imposed on such a foreign supplier. In the absence of such an obligation, the VAT Act imposes a self-assessment collection mechanism on the recipient of imported digitised products. Such a collection mechanism is, however, considered to be ineffective for B2C transactions and poses a threat to the country's VAT base (OECD 2001:27).

For $\mathrm{B} 2 \mathrm{C}$ transactions, the OECD considers a vendor-registration VAT collection mechanism to be the most effective at present. The South African government has to consider the risk of significant revenue losses if a vendor-registration method is not applied and must weigh up this risk against the administrative burden that a vendor-registration method will impose on foreign suppliers. If this method is to be followed, then the VAT Act has to provide at least for a simplified registration procedure for foreign suppliers, as proposed by the OECD.

It is further recommended that the proxies used by the South African VAT Act to determine whether digitised products are consumed in South Africa be brought in line with those proposed by the OECD. It is proposed that the present references to the complex concept of a resident of South Africa for VAT purposes in order to zero-rate the export of digitised products be brought into line with the OECD's business-presence test for B2B transactions and the usual place of residence test for B2C transactions.

The South African VAT Act has to provide guidance to vendors on what is expected of them when they have to verify the VAT status and location of customers. The OECD has proposed that vendors should be able to verify a customer's VAT registration number against a country's vendor registration database, digital certificates and payment system data (OECD 2003d:3). Geolocation software, digital certificates and payment system information can, according to the OECD, be used in order to verify the taxation jurisdiction of a customer (OECD 2003d:7).

Although the provisions of the current South African VAT Act can be applied in order to impose VAT in South Africa on the supply of digitised products, these provisions are not aligned with the principles proposed by the OECD. The above recommendations serve to bring these provisions of the VAT Act into line with the OECD's consumption tax 
principles on e-commerce. Such alignment will contribute to the creation of a fiscal climate in South Africa in which e-commerce can reach its full potential and also contribute to securing the South African VAT base.

\section{Further research areas}

The OECD acknowledges that no single collection mechanism is without difficulties for B2C transactions. The most feasible option in the short-term to protect a country's consumption tax base is considered to be simplified registration of foreign suppliers. It is argued that technology will provide a solution in the longer term. Further research needs to be conducted into the development of an international consumption tax environment that will allow for market-driven technological tax collection solutions.

\section{Bibliography}

Beneke, C. 2003. Deloitte and Touche VAT handbook. $6^{\text {th }}$ edition. Durban: LexisNexis Butterworths.

Carstens, J. \& Lucouw, P. 2004. E-commerce in practice. Vanderbijlpark: Corals.

Canadian Customs and Revenue Authority (CCRA). 2002. GST/HST and electronic commerce. GST/HST Technical Information Bulletin. B 090. July.

De Koker, A.P. \& Kruger, D. 2004. Value-Added Tax in South Africa. Electronic Publication:-LexisNexis Butterworths.

Doernberg, R., Hinnekens, L., Hellerstein, W. \& Li, J. 2001. Electronic commerce and multijurisdictional taxation. The Hague, London, New York: Kluewer Law International.

Du Plessis, B. 2001. E-commerce adds a new dimension. Accountancy SA, August: 15.

Fridensköld, E. 2004. VAT and the Internet: the application of consumption taxes to ecommerce transactions. Information \& Communications Technology Law, 13(4): 175-203.

Hammer, R.M. 2004. Playing OECD TAG - who is IT? Tax Management International Journal, 33(2):106-107.

Lejeune, I. 2002. E-commerce in EU. International Tax Review, 13(7):62-69.

Nunes, T. 1999. South Africa. International Tax Review, 10(8):81-84.

Organisation for Economic Co-operation and Development (OECD). 1998a. Electronic Commerce: Taxation Framework Conditions, A report by the Committee on Fiscal Affairs. October. Paris.

Organisation for Economic Co-operation and Development (OECD). 2001. Consumption tax aspects of Electronic Commerce, A report from working party no. 9 on consumption taxes to the Committee on Fiscal Affairs.

Organisation for Economic Co-operation and Development (OECD). 2003a. About the OECD. http://www.oecd.org/about.html. Accessed 15 August 2003.

Meditari Accountancy Research Vol. 14 No.1 2006:15-28 
Organisation for Economic Co-operation and Development (OECD). 2003b. Implementation issues for taxation of electronic commerce, Report by the Consumption Tax TAG.

Organisation for Economic Co-operation and Development (OECD). 2003c. Electronic Commerce - Commentary on Place of Consumption for Business-to-business Supplies (Business Presence). Consumption Tax Guidance Series: Paper No 1. Centre for Tax Policy and Administration.

Organisation for Economic Co-operation and Development (OECD). 2003d. Electronic Commerce - Verification of Consumer Status and Jurisdiction. Consumption Tax Guidance Series: Paper No 3. Centre for Tax Policy and Administration.

Organisation for Economic Co-operation and Development (OECD). 2003e. Report on Automating Consumption Tax Collection Mechanisms. Committee on Fiscal Affairs.

Organisation for Economic Co-operation and Development (OECD). 2004. The Application of Consumption Taxes to the Trade in International Services and Intangibles. Centre for Tax Policy and Administration.

South Africa. 1962. Income Tax Act, Act 58 of 1962. Pretoria: Government Printer.

South Africa. 1991. Value-Added Tax Act, Act 89 of 1991. Pretoria: Government Printer.

South Africa. 2000. Green Paper on E-Commerce, Department of Communications.

South Africa. 2003. Budget Review, National Treasury.

South Africa. 2004. Budget Review, National Treasury.

South African Rugby Football Union v Commissioner for South African Revenue Service. 61 SATC 406.

Teltscher, S. 2002. Electronic commerce and development: fiscal implications of digitised goods trading. World Development, 30(7):1137-1158.

World Wide Worx. 2006. Online Retail in South Africa 2006 - Broadband and experience the keys to online retail. http://www.theworx.biz/retail06.htm. Accessed 17 July 2006. 